\title{
The Investigation of Ecological Citizenship Levels of Teacher Candidates
}

\author{
Emre Ünal \\ Department of Primary Education, Faculty of Education Nigde Omer Halisdemir University, Nigde, Turkey \\ Email:dr.emreunal@gmail.com
}

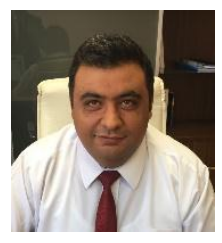

\begin{abstract}
The aim of this study is to investigate the ecological citizenship of teacher candidates in terms of different variables and to determine the variables influencing the ecological citizenship level. The study group consists of 318 voluntary senior students who study at the departments of Primary School Teaching, Social Studies Teaching, Primary School Mathematics Teaching, Science Teaching and Physical Education and Sports Teaching in the faculty of education at a state university. The data were obtained through Ecological Citizenship Scale developed by Karatekin and Uysal (2018). The study was designed in survey method, which is a quantitative research method. The results of the study showed that the ecological citizenship levels of teacher candidates did not differ significantly in terms of the variables of gender, mother educational attainment level, father educational attainment level, membership to non-governmental organizations and membership to student organizations while significant differences were found in terms of the variables of department and participation in social projects.
\end{abstract}

Keywords: Ecology, Citizenship, Teacher candidate, Ecological citizenship, Environment, Environmental problem.

Citation | Emre Ünal (2019). The Investigation of Ecological Citizenship Levels of Teacher Candidates. Asian Journal of Education and Training, 5(2): 329-334.

History:

Received: 1 February 2019

Revised: 13 March 2019

Accepted: 18 April 2019

Published: 31 May 2019

Licensed: This work is licensed under a Creative Commons

Attribution 3.0 License (cc) I

Publisher: Asian Online Journal Publishing Group
Funding: This study received no specific financial support.

Competing Interests: The author declares that there are no conflicts of interests regarding the publication of this paper.

Transparency: The author confirms that the manuscript is an honest, accurate, and transparent account of the study was reported; that no vital features of the study have been omitted; and that any discrepancies from the study as planned have been explained.

sthical: This study follows all ethical practices during writing.
Ethe

\section{Contents}

1. Introduction

References. 


\section{Introduction}

The beginning of environmental problems to threaten the current order can be dated back to the first half of the $19^{\text {th }}$ century; in other words, the industrial revolution. In fact, in this period, the relationship between man and nature began to change in a unidirectional manner to the detriment of nature and environmental problems started to become a threat to human life.

It is stated that, in addition to industrialization, liberalization (Jagers, 2009) and the capitalist economic system (Houser, 2009) are the other reasons for the increase in environmental problems. The reasons for this may be that liberal democracy does not force citizens to be more sensitive towards the environment (Barry, 2001, cited in 2001 by Jagers (2009) and that capitalist economic system has unlimited concepts of production and consumption. Environmental problems emerge from the collective results of the citizens' unsustainable lifestyles, which makes it necessary to ensure that they take ecological considerations and responsibilities into account while trying to overcome environmental problems (Jagers et al., 2014).

The fact that environmental values have an important place in the expression of citizens' environmental responsibility behaviors (Biagi and Ferro, 2011) has led to many studies examining opinions and beliefs of teachers and teacher candidates on environmental education, sustainability and nature in different countries (Cotton, 2006; Munoz et al., 2009; Manolas and Tampakis, 2010; Begum, 2012; Ahi et al., 2017; Uitto and Saloranta, 2017; AarnioLinnanvuori, 2019).

Green et al. (2016) addressed the role of governments in overcoming environmental problems in their study and highlighted the need to handle the solution in the dimensions of citizen and government. Such that, the limited content and structure of environmental education have formed a basis for the idea that the evaluation of related studies in terms of citizenship is more important in the protection of the environment and in creating a sustainable habitat. Considering the issue globally, it is understood from this point of view that environmental concerns have started to be regarded as a problem in various strata of society and that a connection between citizenship and environment is tried to be established especially in the last years (Jelin, 2000; Wolf et al., 2009; Latta and Wittman, 2010). In this sense, ecological citizenship concept is increasingly getting important in solving environmental problems (Latta, 2007). It is evident that the environmental problems, once regarded as local issues, have gained an international dimension with the globalization process. This globalization process leads to the implementation of policies involving approaches different from the traditional approach in both the definition of social problems and the search for political solutions (Sáiz, 2005). The most significant one of these policies is the adoption of the concept of "ecological citizenship", which includes the increase in the environmental sensitivity of citizens. Because, as an ecological citizen, the individual has the responsibility to exhibit behaviors that include the daily lifestyle which will reduce the ecological pressures on nature (Lummis et al., 2017).

In the literature on environment, "ecological citizenship" is frequently associated with "environmental citizenship" whereas the issues that constitute the content of this definition are considered under the names of "sustainable citizenship" and "green citizenship" in some studies (Bell, 2005).

Kenis (2016) stated that ecological citizenship refers to a conscious choice that is intended to change the individual behavior of the individual and to reject practices in which this behavior is guided by economic incentives or advertising campaigns, thereby altering the underlying motivation of environmental action. MacGregor and Szerszynski (2003) expressed environmental citizenship as a personal commitment to learning more about the environment and to taking measures against environmental problems (cited in Bell (2005). On a basic level, ecological citizenship is related to citizens' status, rights and participation processes related to natural environment (Crane et al., 2008). In this context, "ecological citizenship” consists of environmental information, environmental awareness, environmental concern, personality variables, socio-demographic variables, environmental education, environmental literacy and performing environmentally responsible behaviors (Hawthorne and Alabaster, 1999).

As stated by Green et al. (2016), teachers have the potential to influence students' environmental citizenship levels significantly by affecting their knowledge, value, belief and environmental actions. The necessity for every single child to adopt being productive starting from his/her school environment, to know about nature and culture and to be an active practitioner in the protection of nature and culture (p.84) is stated in the document called "Strong Turkey Happy Children Educational Vision 2023" by the Ministry of Education. Also, the need to arrange awareness and skills education programs concerning multiple-literacies such as digital literacy, financial literacy, health literacy, ecological literacy, social media literacy, etc. as the $21^{\text {th }}$ century skills is mentioned under the title of lifelong learning (MEB, 2018). Considering the issue with these dimensions, it can be claimed that teachers will assume important tasks in transferring environmental sensitivities to students. The purpose of this study is to investigate the ecological citizenship levels of teacher candidates in terms of the variables of gender, mother educational attainment level, father educational attainment level, membership to non-governmental organizations, participation in social projects and membership to student organizations.

\section{Methodology}

\subsection{Research Model}

In this study, survey method, which is among quantitative research methods, was used. A survey is a type of research to describe an existing situation as it is Büyüköztürk et al. (2010). In this study, survey method is used as it aims to determine the ecological citizenship levels of teacher candidates in terms of different variables.

\subsection{Study Group}

This study was carried out in 2018-2019 academic year with 318 senior students studying in the faculty of education at a state university. The study group consists of 105 male and 213 female teacher candidates. As for the department variable, the study group includes 131 teacher candidates from the elementary school teaching program, 76 teacher candidates from the science teaching program, 20 teacher candidates from the elementary mathematics teaching program, 32 teacher candidates from the social studies teaching program and 59 teacher candidates from the physical education and sports teaching program. 


\subsection{Data Collection}

In this study, Ecological Citizenship Scale developed by Karatekin and Uysal (2018) was used as the data collection tool. The scale consists of 24 items and 4 sub-dimensions. In the exploratory factor analysis to examine the construct validity of the scale, the total variance was found $49.81 \%$ and the internal consistency coefficient, Cronbach-Alpha, was found as .901 for the whole scale (Karatekin and Uysal, 2018). In the exploratory factor analysis which is the structural validity analysis for this study group, the total variance was $51.32 \%$ and the Cronbach-Alpha internal consistency coefficient was .886 for the whole scale. The Ecological Citizenship Scale is a valid and reliable scale for this study group.

\subsection{Data Analysis}

In order to determine the analysis techniques to be used in the study, it is examined whether or not the data showed normal distribution. For this purpose, kurtosis and skewness were examined. It is stated that the kurtosis value must be between +1 and -1 (George and Mallery, 2010) and the distortion value must be between +1 and -1 (Hair et al., 2013). It was concluded that the kurtosis and skewness values in this study were among the required values and that the data showed normal distribution. As a result, independent t test and one-way analysis of variance were used to analyse the data.

\section{Findings}

The teacher candidates' ecological citizenship levels in terms of gender are given in Table 1.

\begin{tabular}{|c|c|c|c|c|c|}
\hline Gender & n & $\bar{x}$ & $\mathbf{s}$ & $\mathbf{T}$ & p \\
\hline Male & 105 & 3,43 & ,66 & \multirow{2}{*}{1,901} & \multirow{2}{*}{,058 } \\
\hline Female & 213 & 3,56 & ,53 & & \\
\hline
\end{tabular}

The t-test results in Table 1 indicate that ecological citizenship levels of teacher candidates do not differ significantly in terms of their gender. Although the mean scores of female teacher candidates were higher than those of males, no statistically significant difference was found.

The teacher candidates' ecological citizenship levels in terms of the department variable are given in Table 2.

Table-2. The one-way analysis of variance test results showing teacher candidates' ecological citizenship levels in terms of the department variable.

\begin{tabular}{c|c|c|c|c|c|c}
\hline Department & Sum of Squares & Df & Mean Square & F & P & Source of Difference (Scheffe) \\
\hline Between Groups & 4,793 & 4 & 1,198 & & & \\
\cline { 1 - 4 } Within Groups & 101,768 & 313 &, 324 & \multirow{2}{*}{3,697} & \multirow{2}{*}{ SÖ-SBÖ } \\
Total & 106,561 & 317 & & & & IMÖ-SBÖ \\
\hline
\end{tabular}

Source: Calculated from primary data *Level of significance at $\mathrm{p}<0.05$.

According to the one-way analysis of variance test results in Table 2 , ecological citizenship levels of teacher candidates vary significantly in terms of the department variable. Scheffe test was conducted to investigate the source of the difference. It was seen that the difference is between the social studies teacher candidates and the primary school teacher candidates, and social studies teacher candidates and the primary school mathematics teacher candidates. The difference was found to be in favour of the social studies teacher candidates in both situation.

The teacher candidates' ecological citizenship levels in terms of their mothers' educational attainments variable are given in Table 3.

Table-3. The one-way analysis of variance test results showing teacher candidates' ecological citizenship levels in terms of their mothers' educational attainments variable.

\begin{tabular}{|c|c|c|c|c|c|}
\hline $\begin{array}{c}\text { Mothers' educational } \\
\text { attainments }\end{array}$ & Sum of Squares & Df & Mean Square & $\mathbf{F}$ & $\mathbf{P}$ \\
\hline Between Groups &, 522 & 4 &, 130 & \multirow{3}{*}{,386 } & \multirow{3}{*}{, 818} \\
\hline Within Groups & 106,039 & 313 & ,338 & & \\
\hline Total & 106,561 & 317 & & & \\
\hline
\end{tabular}

The figures in Table 3 show that ecological citizenship levels of teacher candidates do not differ significantly in terms of the mothers' educational attainment variable. It was found that mother educational attainment levels of teacher candidates had no effect on their ecological citizenship levels.

The teacher candidates' ecological citizenship levels in terms of their fathers' educational attainments variable are given in Table 4.

Table-4. The one-way analysis of variance test results showing teacher candidates' ecological citizenship levels in terms of their fathers' educational attainments variable.

\begin{tabular}{|c|c|c|c|c|c|}
\hline $\begin{array}{c}\text { Fathers' educational } \\
\text { attainments }\end{array}$ & Sum of Squares & Df & Mean Square & $\mathbf{F}$ & $\mathbf{P}$ \\
\hline Between Groups & 1,808 & 5 & ,362 & \multirow{3}{*}{1,080} & \multirow{3}{*}{, 371} \\
\hline Within Groups & 104,753 & 312 & ,335 & & \\
\hline Total & 106,561 & 317 & & & \\
\hline
\end{tabular}

Source: Calculated from primary data *Level of significance at $\mathrm{p}<0.05$. 
As it can be seen in Table 4, ecological citizenship levels of teacher candidates do not differ significantly in terms of their fathers' educational attainment levels. The figures indicate that fathers' educational attainment levels have no effect on the teacher candidates' ecological citizenship levels.

The teacher candidates' ecological citizenship levels in terms of membership to non-governmental organizations (NGOs) are given in Table 5 .

Table-5. The independent t-test results showing teacher candidates' ecological citizenship levels in terms of membership to NGOs.

\begin{tabular}{c|c|c|c|c|c}
\hline NGOs Membership & $\mathbf{n}$ & $\overline{\boldsymbol{x}}$ & $\mathbf{s}$ & $\mathbf{T}$ & $\mathbf{p}$ \\
\hline Yes & 44 & 3,67 &, 53 & \multirow{2}{*}{1,918} & \multirow{2}{*}{, 056} \\
\hline No & 274 & 3,49 &, 58 & & \\
\hline \multicolumn{2}{l|}{ Source: Calculated from primary data *Level of significance at $\mathrm{p}<0.05}$.
\end{tabular}

According to the figures in Table 5, ecological citizenship levels of teacher candidates do not show a significant difference according to their membership to NGOs. Although the mean scores of the teacher candidates who are members of NGOs are higher than those of the teacher candidates who have no membership to any NGOs, there is no statistically significant difference.

The teacher candidates' ecological citizenship levels in terms of participation in social projects variable are given in Table 6.

Table-6. The independent t-test results showing teacher candidates' ecological citizenship levels in terms of participation in social projects variable.

\begin{tabular}{c|c|c|c|c|c}
\hline Participation & $\mathbf{n}$ & $\overline{\boldsymbol{x}}$ & $\mathbf{S}$ & $\mathbf{T}$ & $\mathbf{P}$ \\
\hline Yes & 124 & 3,64 &, 60 & \multirow{2}{*}{2,975} & \multirow{2}{*}{, 003} \\
\hline No & 194 & 3,44 &, 56 & \\
\hline Source: Calculated from primary & * &
\end{tabular}

Source: Calculated from primary data *Level of significance at $\mathrm{p}<0.05$.

The independent t-test results in Table 6 show that ecological citizenship levels of teacher candidates vary significantly in terms of their participation in social projects. The mean scores of the teacher candidates who participate in social projects are higher than those of the teacher candidates who do not take part in social projects. In this case, it can be concluded that participating in any social project increases the ecological citizenship levels of teacher candidates.

The teacher candidates' ecological citizenship levels in terms of membership to student organizations variable are given in Table 7 .

Table-7. The independent t-test results showing teacher candidates' ecological citizenship levels in terms of membership to student organizations variable.

\begin{tabular}{c|c|c|c|c|c}
\hline Student Organization & $\mathbf{n}$ & $\overline{\boldsymbol{x}}$ & $\mathbf{S}$ & $\mathbf{T}$ & $\mathbf{p}$ \\
\hline Yes & 93 & 3,46 &, 60 & \multirow{2}{*}{1,090} & \multirow{2}{*}{, 276} \\
\hline No & 225 & 3,54 &, 57 & & \\
\hline \multicolumn{5}{l}{ Source: Calculated from primary data *evel of significance at $\mathrm{p}<0.05}$.
\end{tabular}

The figures in Table 7 indicate that ecological citizenship levels of teacher candidates do not differ significantly in terms of their membership to student organizations. It can be concluded that membership to a student organization has no effect on ecological citizenship levels.

\section{Results and Discussion}

The concept of ecological citizenship is still debated today (Karatekin and Uysal, 2018) because it contains many definitions such as individual information, environmental literacy and attitude towards the environment. In this respect, there are no comprehensive studies on the concept of ecological citizenship in the literature. Also, the concept hasn't yet been addressed on the basis of different variables in the studies that handle it indirectly. Likewise, the ecological citizenship scale developed in our country has not been adequately addressed in terms of variables either. It is thought that this study will contribute to the field in this context.

The first one of the variables that are taken into consideration in relation to ecological citizenship levels of teacher candidates is the gender variable. Although the mean scores of female teacher candidates are higher than those of the male teacher candidates, there is no statistically significant difference in terms of gender. The reasons for the high mean scores of female teacher candidates may be that society considers the teaching profession as a woman's profession in which women can perform family and business life together and that women internalize this social value (Dogan and Coban, 2009) and environmental sensitivities more than do men. It can be stated that women's critical thinking tendencies are higher (Can and Kaymakçı, 2008) and that, in terms of critical thinking tendency, women have more attitudes and values such as approaching a problem from a sceptical and curious point of view, analysing decisions while making decisions about the solution of the problem, being planned, reasoning the decisions out, questioning and criticizing the events encountered, thinking about the details of the situation, conducting in-depth observations, fulfilling the responsibility given, taking the appropriate conditions into consideration during the decision-making process and being tolerant (Ylldırım, 2018), which supports the finding obtained in the research.

It was found that ecological citizenship levels of teacher candidates differ significantly in terms of the departments in which they study. The difference was found to be between the social studies teacher candidates and the primary school teacher candidates, and social studies teacher candidates and the primary school mathematics teacher candidates. In both situations, the difference was in favour of the social studies teacher candidates. The reason for this result may be that this process is managed more effectively in some courses (Social Project 
Development, Citizenship Knowledge, Today's World Issues) which are only included in the undergraduate programs of social studies teacher candidates.

It was concluded that the ecological citizenship levels of teacher candidates do not differ significantly in terms of mother and father educational attainment levels. The educational attainment levels of teacher candidates' fathers and mothers have no effect on ecological citizenship levels of the teacher candidates. Considering that the teacher candidates in the study group are senior students, this result is thought to stem from the idea that their personal values, beliefs and attitudes are already internalized.

Ecological citizenship levels of teacher candidates do not show a significant difference in terms of their membership to NGOs. Although the mean scores of the teacher candidates who are members of a NGO are higher than those of the teacher candidates who have no membership to any NGOs, no statistically significant difference was found. It can be inferred from this result that teacher candidates who are members of NGOs have more democratic values and adopt democratic values more (Akin and Ozdemir, 2009) and that membership to NGOs enable individuals to be active in environmental development and problem solving, improving their social involvement competencies (Ersoy, 2014).

Ecological citizenship levels of teacher candidates vary significantly in terms of participation in social projects variable. The mean scores of the teacher candidates who participate in social projects are higher than those of the teacher candidates who do not take part in any social projects. In this case, it can be concluded that taking part in any social project increases the ecological citizenship levels of teacher candidates. Teacher candidates are supposed to gain social sensitivity and responsibility, have entrepreneurship and self-confidence, integrate into society and take the leadership role in society in the pre-service period (Gökçe, 2011). In this context, it is thought that increasing the number of social projects in teacher education and encouraging the participation of teacher candidates actively in social projects are of great importance.

\section{References}

Aarnio-Linnanvuori, E., 2019. How do teachers perceive environmental responsibility? Environmental Education Research, 25(1): 4661.Available at: https://doi.org/10.1080/13504622.2018.1506910.

Ahi, B., S. Balci and F. Alisinanoğlu, 2017. Exploring Turkish preservice teachers' mental models of the environment: Are they related to gender and academic level? The Journal of Environmental Education, 48(3): 182-195.Available at: https://doi.org/10.1080/00958964.2016.1267102.

Akin, M. and M. Ozdemir, 2009. Examining the democratic values of teacher candidates in terms of various variables. Ankara University Faculty of Educational Sciences Journal, 42(2): 183-198.

Begum, S., 2012. A secondary science teacher's beliefs about environmental education and its relationship with the classroom practices. International Journal of Social Sciences and Education, 2(1): 10-29.

Bell, D.R., 2005. Liberal environmental citizenship. Environmental Politics, 14(2): 179-194.Available at: https://doi.org/10.1080/09644010500054863

Biagi, M. and M. Ferro, 2011. Ecological citizenship and social representation of water: Case study in two argentine cities. Sage Open, 1(2): 1-8.Available at: https://doi.org/10.1177/2158244011417897.

Büyüköztürk, Ş., E.K. Çakmak, Ö.E. Akgün, S. Karadeniz and F. Demirel, 2010. Scientific research methods. 7th Edn., Ankara: Pegem Akademi.

Can, S. and G. Kaymakçı, 2008. Critical thinking tendencies of teacher candidates. Education Sciences, 10(2): 66-83.

Cotton, D.R., 2006. Implementing curriculum guidance on environmental education: The importance of teachers' beliefs. Journal of Curriculum Studies, 38(1): 67-83.Available at: https://doi.org/10.1080/00220270500038644.

Crane, A., D. Matten and J. Moon, 2008. Ecological citizenship and the corporation: Politicizing the new corporate environmentalism. Organization \& Environment, 21(4): 371-389.Available at: https://doi.org/10.1177/1086026608326075

Dogan, T. and A.E. Coban, 2009. Examining the relationship between the attitudes of the faculty of education and the attitudes towards teaching profession. Education and Science, 34(153): 157-168.

Ersoy, A.F., 2014. Experiences of social studies teacher candidates' active citizenship: Example of non-governmental organizations. Ankara University Faculty of Educational Sciences Journal, 47(2): 65-88.

George, D. and M. Mallery, 2010. SPSS for windows step by step: A simple guide and reference, 17.0 update. 10th Edn., Boston: Pearson.

Gökçe, N., 2011. Social studies pre-service teachers' evaluations on community service practices. International Journal of Human Sciences, 8(2): 176-194

Green, C., W. Medina-Jerez and C. Bryant, 2016. Cultivating environmental citizenship in teacher education. Teaching Education, 27(2): 117-135.Available at: https://doi.org/10.1080/10476210.2015.1043121.

Hair, J.F., W.C. Black, B.J. Babin and R.E. Anderson, 2013. Multivariate data analysis: Pearson new international edition. Essex: Pearson Education Limited.

Hawthorne, M. and T. Alabaster, 1999. Citizen 2000: Development of a model of environmental citizenship. Global Environmental Change, 9(1): 25-43.Available at: https://doi.org/10.1016/s0959-3780(98)00022-3.

Houser, N.O., 2009. Ecological democracy: An environmental approach to citizenship education. Theory \& Research in Social Education, 37(2): 192-2 14.Available at: https://doi.org/10.1080/00933 104.2009.10473394.

Jagers, S.C., 2009. In search of the ecological citizen. Environmental Politics, 18(1): 18-36.Available at: https://doi.org/10.1080/09644010802624751.

Jagers, S.C., J. Martinsson and S. Matti, 2014. Ecological citizenship: A driver of pro-environmental behaviour? Environmental Politics, 23(3): 434-453.Available at: https://doi.org/10.1080/09644016.2013.835202.

Jelin, E., 2000. Towards a global environmental citizenship? Citizenship Studies, 4(1): 47-63.Available at: https://doi.org/10.1080/136210200110021.

Karatekin, K. and C. Uysal, 2018. Ecological citizenship scale development study. International Electronic Journal of Environmental Education, 8(2): 82-104.

Kenis, A., 2016. Ecological citizenship and democracy: Communitarian versus agonistic perspectives. Environmental Politics, $25(6)$ : 949970.Available at: https://doi.org/10.1080/09644016.2016.1203524.

Latta, A. and H. Wittman, 2010. Exploraciones/explorations. European Review of Latin American and Caribbean Studies, 89(October): 107116.

Latta, P.A., 2007. Locating democratic politics in ecological citizenship. Environmental Politics, 16(3): 377-393.Available at: https://doi.org/10.1080/09644010701251631.

Lummis, G.W., J.E. Morris, G. Lock and J. Odgaard, 2017. The influence of ecological citizenship and political solidarity on Western Australian student teachers' perceptions of sustainability issues. International Research in Geographical and Environmental Education, 26(2): 135-149.Available at: https://doi.org/10.1080/10382046.2016.1235359.

MacGregor, S. and B. Szerszynski, 2003. Environmental citizenship and the administration of life. Paper Presented at 'Citizenship and the Environment' Workshop, Newcastle University, 4-6 September.

Manolas, E. and S. Tampakis, 2010. Environmental responsibility: Teachers' views. Journal of Teacher Education for Sustainability, 12(1): 27-36.Available at: https://doi.org/10.2478/v 10099-009-0044-z.

MEB, 2018. Happy children educational vision 2023 strong Turkey. MEB, Ankara: Turkey. Available from http://2023vizyonu.meb.gov.tr/doc/2023_EGITIM_VIZYONU.pdf [Accessed 10.01.2019]. 
Munoz, F., F. Bogner, P. Clement and G.S. Carvalho, 2009. Teachers' conceptions of nature and environment in 16 countries. Journal of Environmental Psychology, 29(4): 407-413.Available at: https://doi.org/10.1016/j.jenvp.2009.05.007.

Sáiz, V.Á., 2005. Globalisation, cosmopolitanism and ecological citizenship. Environmental Politics, 14(2): 163-178.Available at: https://doi.org/10.1080/09644010500054848.

Uitto, A. and S. Saloranta, 2017. Subject teachers as educators for sustainability: A survey study. Education Sciences, 7(1): 1-19.Available at: https://doi.org/10.3390/educsci7010008.

Wolf, J., K. Brown and D. Conway, 2009. Ecological citizenship and climate change: Perceptions and practice. Environmental Politics, 18(4): 503-521.Available at: https://doi.org/10.1080/09644010903007377.

Ylldırım, B., 2018. Investigation of empathic and critical thinking tendencies of prospective science teachers. Firat University Institute of Educational Sciences, Unpublished Master Thesis. 